\title{
Clinical efficacy of liver resection combined with adjuvant microwave coagulation for patients with hepatocellular carcinoma: a promising approach to minimize recurrence?
}

\author{
Emanuele Felli ${ }^{1,2,3}$, Zineb Cherkaoui $^{1,2}$, Patrick Pessaux ${ }^{1,2,3}$ \\ ${ }^{1}$ Digestive and Endocrine Surgery, HPB Unit, Nouvel Hopital Civil, University of Strasbourg, Strasbourg, France; ${ }^{2}$ IHU Strasbourg - Institut de \\ Chirurgie Guidée par l'image, Strasbourg, France; ${ }^{3}$ Institut of Viral and Liver Disease, Inserm U1110, Strasbourg, France \\ Correspondence to: Patrick Pessaux, MD, PhD. Digestive and Endocrine Surgery, Nouvel Hopital Civil, University of Strasbourg, 1, place de l'Hôpital, \\ 67000 Strasbourg, France. Email: patrick.pessaux@chru-strasbourg.fr. \\ Comment on: Zhang T, Wang M, Zhang X, et al. Analysis of the clinical efficacy of liver resection combined with adjuvant microwave coagulation for \\ patients with hepatocellular carcinoma. Ann Transl Med 2020;8:585.
}

Submitted May 28, 2020. Accepted for publication Jun 11, 2020.

doi: $10.21037 /$ atm-2020-114

View this article at: http://dx.doi.org/10.21037/atm-2020-114

We read with great interest the article of Zhang et al. (1) concerning the clinical relevance of liver resection associated with adjuvant microwave coagulation for patients with BCLC stage A hepatocellular carcinoma (HCC). At present, liver resection is performed as a curative measure for the treatment of HCC in a subgroup of patients with no extra hepatic disease. The goals of surgical approach for HCC is to obtain a compromise between R0 resections with negative margin and preservation of adequate function of the future remnant liver. Due to the improvement of the safety of surgical resection, the role of hepatectomy for HCC has increase including selected patients with preserved liver function and small tumors (alternative of ablation), tumors within Milan criteria (alternative of transplantation), and patients with lesion $>5 \mathrm{~cm}$ and huge HCC.

As high rate of postoperative recurrence is observed following resection, international guidelines are very restrictive concerning indication to surgical treatment, also considering that the ideal treatment for HCC on cirrhotic liver is liver transplantation (2). Nevertheless, the practical attitude of hepato-biliary centers around the world often are in disagreement with the BCLC flow chart, especially in the presence of macrovascular thrombosis because of higher survival rates reported after surgical resection in comparison to systemic palliative treatment (3). To minimize recurrence and prolong overall survival different strategies have been adopted, the most accepted one is the anatomical liver resection that should be in theory considered the gold standard of resection, based on the concept of intrahepatic portal spread of the disease (4-8). Other adjuvant treatments, such as interferon (IFN)-a, chemokine-induced killer cells, transcatheter chemoembolization (TACE) and anti-hepatitis $\mathrm{B}$ virus (HBV) agents, sorafenib and anti-PD-1 antibodies failed to improve recurrence-free survival (RFS). Microwave coagulation was proposed as an adjuvant therapy. In this study, the authors reported that liver resection associated with intraoperative adjuvant microwave coagulation had a better result than treatment with liver resection alone. This approach should ideally minimize intrahepatic spreading of tumoral cells during and after resection (9), optimizing as well the transection line with lower blood loss as reported in other studies (10). The concept is interesting but there are several biases to consider, in particular the fact that no specific report is present concerning the type of resection in the two groups and no information about histology of the specimens, especially the microvascular invasion? The same consideration has to be done to intraoperative blood loss and transfusions, as they are known risk factors of recurrence. In conclusion, the Achille's heel of liver resection for HCC is recurrence. Different methods have been proposed but at present no one demonstrated its efficacy. The clinical relevance of liver resection associated with adjuvant microwave coagulation could be one potential approach but further studies are needed to consider this strategy in routine clinical practice. Multidisciplinary meeting is essential in the management of patients with 
HCC to propose and coordinate the optimal therapeutic strategy possible for these high-risk patients.

\section{Acknowledgments}

Funding: None.

\section{Footnote}

Provenance and Peer Review: This article was commissioned by the editorial office, Annals of Translational Medicine. The article did not undergo external peer review.

Conflicts of Interest: All authors have completed the ICMJE uniform disclosure form (available at http://dx.doi. org/10.21037/atm-2020-114). The authors have no conflicts of interest to declare.

Ethical Statement: The authors are accountable for all aspects of the work in ensuring that questions related to the accuracy or integrity of any part of the work are appropriately investigated and resolved.

Open Access Statement: This is an Open Access article distributed in accordance with the Creative Commons Attribution-NonCommercial-NoDerivs 4.0 International License (CC BY-NC-ND 4.0), which permits the noncommercial replication and distribution of the article with the strict proviso that no changes or edits are made and the original work is properly cited (including links to both the formal publication through the relevant DOI and the license). See: https://creativecommons.org/licenses/by-nc-nd/4.0/.

\section{References}

1. Zhang T, Wang M, Zhang X, et al. Analysis of the clinical efficacy of liver resection combined with adjuvant

Cite this article as: Felli E, Cherkaoui Z, Pessaux P. Clinical efficacy of liver resection combined with adjuvant microwave coagulation for patients with hepatocellular carcinoma: a promising approach to minimize recurrence? Ann Transl Med 2020;8(18):1123. doi: 10.21037/atm-2020-114 microwave coagulation for patients with hepatocellular carcinoma. Ann Transl Med 2020;8:585.

2. Xiong Q, Geng TT, He L, et al. Harm and Benefits of Salvage Transplantation for Hepatocellular Carcinoma: An Updated Meta-analysis. Transplant Proc 2016;48:3336-47.

3. Torzilli G, Belghiti J, Kokudo N, et al. A snapshot of the effective indications and results of surgery for hepatocellular carcinoma in tertiary referral centers: is it adherent to the EASL/AASLD recommendations?: an observational study of the HCC East-West study group. Ann Surg 2013;257:929-37.

4. Wakai T, Shirai Y, Sakata J, et al. Anatomic resection independently improves long-term survival in patients with T1-T2 hepatocellular carcinoma. Ann Surg Oncol 2007;14:1356-65.

5. Regimbeau JM, Kianmanesh R, Farges O, et al. Extent of liver resection influences the outcome in patients with cirrhosis and small hepatocellular carcinoma. Surgery 2002;131:311-7.

6. Eguchi S, Kanematsu T, Arii S, et al. Comparison of the outcomes between an anatomical subsegmentectomy and a non-anatomical minor hepatectomy for single hepatocellular carcinomas based on a Japanese nationwide survey. Surgery 2008;143:469-75.

7. Cho YB, Lee KU, Lee HW, et al. Anatomic versus non-anatomic resection for small single hepatocellular carcinomas. Hepatogastroenterology 2007;54:1766-9.

8. Hasegawa K, Kokudo N, Imamura H, et al. Prognostic impact of anatomic resection for hepatocellular carcinoma. Ann Surg 2005;242:252-9.

9. Imura S, Shimada M, Utsunomiya T, et al. Ultrasoundguided microwave coagulation assists anatomical hepatic resection. Surg Today 2012;42:35-40.

10. Eisele RM, Denecke T, Glanemann M, et al. Minimalinvasive microwave coagulation therapy for liver tumours: laparoscopic and percutaneous access. Zentralbl Chir 2014;139:235-43. 